\title{
Determinants of Pre-Anemia among Healthy University Students
}

\author{
Muamar MA Shaheen $^{1 *}$ and Islam Hassouneh ${ }^{2}$ \\ ${ }^{1}$ Faculty of Pharmacy and Medical Sciences, Hebron University, Hebron, Palestine \\ ${ }^{2}$ Faculty of Administrative Sciences and Informatics, Palestine Polytechnic University \\ (PPU), Hebron, Palestine \\ *Corresponding Author: Muamar MA Shaheen, Faculty of Pharmacy, Hebron \\ University, Hebron, Palestine.
}

\author{
Received: April 04, 2020 \\ Published: May 28, 2020 \\ (C) All rights are reserved by Muamar MA \\ Shaheen and Islam Hassouneh.
}

\begin{abstract}
Background: Hemoglobin levels might not predict pre-anemic states neither do they predict signs and symptoms of iron deficiency in healthy people. Poor dietary habits along with other risk factors might predict risk of developing anemia.

Aims: We aim at determining the risk factors associated with prediction of pre-anemia and the level of awareness of anemia among students.

Methods: This is a cross- sectional study where capillary blood samples were collected from a random sample of 200 healthy university students on campus during February 2018. Hematocrit and hemoglobin values were determined for all students. A previously validated questionnaire was distributed on participants to collect social, health and dietary data.

Results: The prevalence of Iron Deficiency Anemia among students was $22 \%$. It was shown that students dietary habits had a moderate effect on Iron Deficiency Anemia, arithmetic mean \pm SD was (2.97 \pm 0.54$)$. There was $1.3-2.1$ folds increase in risk of Iron Deficiency Anemia for students with poor dietary habits. Almost $57 \%$ of students who have low hemoglobin levels have normal Body Mass Index (BMI). On the other hand, $22.7 \%$ of students who have low hemoglobin levels were either overweight or obese. There was a significance difference in anemia prevalence $(\alpha=0.002)$ between underweight and overweight groups. The level of awareness of major aspects of anemia ranged from moderate to high, mean \pm SD $(2.44 \pm 1.35)$ to (3.88 \pm 1.14$)$.

Conclusion: Overweight, poor dietary habits as related to iron intake and low level of awareness of anemia were associated with high prevalence of pre-and/or anemic states. Whether eating disorder lead to anemia or anemia lead to eating behavior disorder, need to be investigated.
\end{abstract}

Keywords: Hemoglobin Level; Iron-Deficiency Anemia; Iron-Rich Diet; Eating Behavior

\section{Introduction}

Anemia is a condition in which hemoglobin $(\mathrm{Hb})$ levels falls below normal limits [1,2]. In fact, there are more than four hundred different types of anemia with different attributing causes $[2,4]$. It could be defined as a deficiency in Red Blood Cells (RBCs) [1,3], or a reduction in their oxygen-carrying capacity to a level insufficient to meet physiologic needs [4]. Anemia is a global burden that afflicts low-, middle- and high-income countries. It has significant adverse health consequences, and a negative impact on social and economic development and scholastic achievement [5-9]. Anemia causes a range from improper nutrition to inheritance $[10,11]$.

The most common types of anemia are: megaloblastic anemia, pernicious anemia, aplastic anemia, thalassemia, sickle cell anemia, hemolytic anemia and Iron Deficiency Anemia (IDA) [9,11].
Regardless to type of anemia, symptoms are the same (weakness, general fatigue, paleness of the skin, gums, eyes and nail beds) [11].

One of the studies which was conducted in Hebron and Ramallah cities, in Palestine, among adolescent showed that the prevalence of anemia was $22.5 \%$ and $6.0 \%$ among boys in Hebron and Ramallah, respectively. It was $9.2 \%$ and $9.3 \%$ in girls in the 2 cities respectively [12]. In Palestine, only one study showed that the overall prevalence of IDA was $33.5 \%$ with no significant differences between boys and girls [13]. The prevalence of IDA was not high, $4.5 \%$, whereas the prevalence of iron deficiency without anemia was high, $31.5 \%$ [13]. IDA is the most common type of nutritional anemia [13-16].

IDA, where Hb concentration falls below a defined limit [17], is considered as the most prevalent form of micronutrient deficiency 
worldwide [18]. It is considered as an indicator and parameter for iron deficiency where people with this type of anemia might have an abnormal volume of RBCs [19].

Our study tackles the issue of hidden anemia and pre-anemic long standing negative iron balance. The aim of this study is to determine the prevalence of low $\mathrm{Hb}$ levels among university students and its relation to their dietary habits.

Furthermore, a questionnaire was used to study the level of awareness and knowledge about signs and symptoms of anemia and healthy eating habits.

\section{Materials and Methods}

Capillary blood samples were collected from a convenient sample of 200 healthy university students (73\% females) at Hebron University campus during February 2018. All blood samples were analyzed using Hettich ZENTRIFUGEN Hematocrit 24 device. Hematocrit value was divided by three in order to calculate $\mathrm{Hb}$ level for each student. An informed consent was taken from all participants. A well-validated and standardized questionnaire with slight modifications was distributed among all participants to collect sociodemographic, dietary habits, health status, anthropometric data and level of students' awareness about anemia.

All data were analyzed using SPSS version 20S. Arithmetic means and standard deviations for dietary habits were calculated to assess the impact of dietary habits on IDA from the point of view of students. One-Sample Statistics (T-Test) of dietary habits and diet management by Hebron University students was performed. An ANOVA (F-test) for polychotomous variables was performed. All students with communicable diseases, coagulopathy, hemophilia, and/or confirmed anemia were excluded from the study.

\section{Results}

The majority of participants in this study were females, (73.0\%), distributed into two age categories: 17 - 19 year old, $n=91$ and > 20 years old, $\mathrm{n}=91$. When asking about medical history, a total of $75 \%$ of individuals (146) said that they do not have diabetes, compared with $23.5 \%$ who said that they have diabetes and $3.5 \%$ do not know. Statistics also indicate that $87.5 \%$ of the respondents were not overweight or obese (See table 1).

The results showed that the prevalence of low Hb levels was $22 \%$ (44 students who have mild to moderate anemia divided by 200 , the total number of students). The prevalence was mostly among female students, $21.5 \%$ (43/200). While, only one male student had mild anemia, $97.7 \%$ of females had anemia. More spe-

\begin{tabular}{|c|c|c|c|}
\hline \multicolumn{2}{|r|}{ Variables } & $\begin{array}{l}\text { Frequency } \\
\text { (n) }\end{array}$ & $\begin{array}{c}\text { Percent } \\
\%\end{array}$ \\
\hline \multirow[t]{2}{*}{ Gender } & Male & 54 & 27.0 \\
\hline & Female & 146 & 73.0 \\
\hline \multirow[t]{2}{*}{ Age } & 17 - 19 years & 91 & 45.5 \\
\hline & $>19$ vears & 91 & 45.5 \\
\hline \multirow[t]{6}{*}{ Residency } & & 119 & 59.5 \\
\hline & 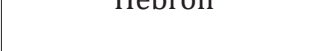 & 61 & 30.5 \\
\hline & Village & 12 & 60 \\
\hline & Camp & & \\
\hline & Bethlehem & 3 & 1.5 \\
\hline & Other & 2 & 1.0 \\
\hline \multirow{4}{*}{$\begin{array}{l}\text { Father } \\
\text { education }\end{array}$} & Primary school or less & 28 & 14.0 \\
\hline & Secondary & 74 & 37.0 \\
\hline & University or more & 89 & 44.5 \\
\hline & Not educated & 7 & 3.5 \\
\hline \multirow{4}{*}{$\begin{array}{l}\text { Mother } \\
\text { education }\end{array}$} & Primary school or less & 23 & 11.5 \\
\hline & Secondary & 94 & 47.0 \\
\hline & University or more & 75 & 37.5 \\
\hline & Not educated & 7 & 3.5 \\
\hline \multirow[t]{7}{*}{ Father work } & Employee & 44 & 22.0 \\
\hline & Business man & 57 & 28.5 \\
\hline & Worker & 71 & 35.5 \\
\hline & Retired & 17 & 8.5 \\
\hline & No job & 4 & 2.0 \\
\hline & Other & 1 & 0.5 \\
\hline & Dead & 1 & 0.5 \\
\hline \multirow{4}{*}{$\begin{array}{l}\text { Mother } \\
\text { work }\end{array}$} & Worker & 3 & 1.5 \\
\hline & Employee & 47 & 23.5 \\
\hline & Housekeeper & 141 & 70.5 \\
\hline & Other & 4 & 2.0 \\
\hline \multirow{4}{*}{$\begin{array}{l}\text { Monthly } \\
\text { income } \\
\text { (NIS) }\end{array}$} & $<2000$ NIS* & 25 & 12.5 \\
\hline & 2000 - 2999 NIS & 53 & 26.5 \\
\hline & 3000 - 3999 NIS & 42 & 21.0 \\
\hline & $>4000$ NIS & 75 & 37.5 \\
\hline
\end{tabular}




\begin{tabular}{|c|c|c|c|}
\hline College & $\begin{array}{c}\text { Sharia (Islamic } \\
\text { religion) } \\
\text { Science and } \\
\text { technology } \\
\text { Agriculture } \\
\text { Finance and } \\
\text { management } \\
\text { Nursing } \\
\text { Pharmacy and } \\
\text { medical sciences } \\
\text { Law and political } \\
\text { science } \\
\text { Information } \\
\text { technology } \\
\text { Arts }\end{array}$ & $\begin{array}{c}2 \\
9 \\
12 \\
21 \\
11 \\
24 \\
30 \\
9 \\
68\end{array}$ & $\begin{array}{l}1.0 \\
4.5 \\
6.0 \\
10.5 \\
5.5 \\
12.0 \\
15.0 \\
4.5 \\
34.0\end{array}$ \\
\hline \multirow[t]{2}{*}{$\begin{array}{l}\text { Medical } \\
\text { History }\end{array}$} & $\begin{array}{c}\text { Diabetes } \\
\text { No } \\
\text { Yes } \\
\text { Don't know }\end{array}$ & $\begin{array}{c}146 \\
47 \\
7\end{array}$ & $\begin{array}{r}73.0 \\
23.5 \\
3.5\end{array}$ \\
\hline & $\begin{array}{c}\text { Obesity } \\
\text { No } \\
\text { Yes } \\
\text { Don't Know }\end{array}$ & $\begin{array}{c}175 \\
20 \\
5\end{array}$ & $\begin{array}{r}87.5 \\
10.0 \\
2.5\end{array}$ \\
\hline
\end{tabular}

Table 1: Demographic Characteristics of Participants (frequencies and percentages).

* US\$ = 3.55 NIS (New Israeli Sheikels).

cifically, moderate anemia was observed in $34.1 \%$ of females and mild in $63.6 \%$ of them (See table 2 ).

In our study we adopted the definition of anemia in females as any $\mathrm{Hb}$ level $<12 \mathrm{gm} / \mathrm{dl}$. Having this said, the prevalence of anemia among female students was $23.0 \%$ and for male students was 0.005 .

In order to study the effect of students' dietary habits on IDA, arithmetic means and standard deviations for dietary habits were calculated from the viewpoint of Hebron University students.

Data showed that students' dietary habits had a moderate effect on IDA, arithmetic mean \pm SD was $(2.97 \pm 0.54)$. The effect of diet was also moderate for both genders, arithmetic mean \pm SD was $(3.07 \pm 0.48)$ and $(2.83 \pm 0.57)$ for females and males, respectively.

One-Sample Statistics (T-Test) for the mean of each question on dietary habits as weighed by Hebron University students, Diet Management, indicated the following:

\begin{tabular}{|l|c|c|c|c|}
\hline \multirow{2}{*}{ Hb category* } & & \multicolumn{2}{|c|}{ Gender } & \\
\hline & & Male & Female & Total \\
\hline $\begin{array}{l}\text { Moderate ane- } \\
\text { mia }(8-10 \mathrm{~g} / \mathrm{dl})\end{array}$ & Count & 0 & 15 & 15 \\
\cline { 2 - 5 } & $\%$ of Total & $0.0 \%$ & $34.1 \%$ & $34.1 \%$ \\
\hline \multirow{2}{*}{$\begin{array}{l}\text { Mild anemia }(10 \\
-11 \mathrm{~g} / \mathrm{dl})\end{array}$} & Count & 1 & 28 & 29 \\
\cline { 2 - 5 } & $\%$ of Total & $2.3 \%$ & $63.6 \%$ & $65.9 \%$ \\
\hline Total & Count & 1 & 43 & 44 \\
\hline & $\%$ of Total & $2.3 \%$ & $97.7 \%$ & $100.0 \%$ \\
\hline
\end{tabular}

Table 2: Hemoglobin categories by gender cross-tabulation based on WHO iron-deficiency anemia classification.

"According to WHO, anemia is classified into three categories; (1) severe anemia with the $\mathrm{Hb}=3-7 \mathrm{~g} / \mathrm{dl}$, (2) moderate anemia with

$\mathrm{Hb}=8-10 \mathrm{~g} / \mathrm{dl}$ and (3) mild anemia with $\mathrm{Hb}=10-11 \mathrm{~g} / \mathrm{dl}$.

Dietary habits with most impact on anemia expressed as average \pm SD as follows:

- $\quad$ Does the meal contain fruits and vegetables? $(3.60 \pm 1.03)$

- $\quad$ Does the meal contain meat? $(3.47 \pm 1.1)$

- $\quad$ Do you have breakfast daily? $(3.3 \pm 1.18)$

- $\quad$ Does the meal contain beans? $(3.26 \pm 0.99)$

- $\quad$ Do you have 1 - 3 snacks between main meals daily? (3.23 \pm 1.2 ).

The least important dietary habits (low level):

- $\quad$ Drinking dairy milk immediately after meals, average \pm SD $(2.2 \pm 1.04)$.

- Drinking tea within half an hour of meals, was at moderate level, $(2.54 \pm 1.14)$.

- Whether the meal contains Spanish and lattice had moderate level too, $(2.79 \pm 1.07)$.

One-Sample Statistics (T-Test) for knowledge of students on Iron Deficiency Anemia revealed low knowledge on fundamental aspects of anemia.

On the high level, students think anemia could be treated with food, average \pm SD $(3.88 \pm 1.14)$.

Anemia is feeling of drowsiness, tiredness, sleepiness, loss of appetite, and hair loss was rated high in the test; (3.85 \pm 1.21 ). Majority of students thought tea increases iron absorption, $(2.82$ \pm 1.41 ), on high level.

The least important paragraph was, "There is no relationship between iron and anemia". 
It was rated moderately with average $(2.43 \pm 1.34)$.

When assessing knowledge of students on specific aspects of anemia, it was found that the majority of students think that iron deficiency can be treated with food alone. This manifested on our scale as high level with average mean \pm SD $(3.88 \pm 1.14)$. When asked about symptoms of anemia such as feeling of drowsiness, tiredness, sleepiness, loss of appetite and hair loss, there answers came positive on high level with an average mean \pm SD $(3.86 \pm$ 1.22). whether drinking tea increases iron absorption, came in second place with average $(2.82 \pm 1.42)$. "There is no relationship between iron and anemia" was the least important factor. It came on moderate level with average mean \pm SD $(2.44 \pm 1.35)$.

An estimation of the risk of dietary habits on IDA revealed significant relationship. There was 1.7 folds risk of getting IDA if student did not take a daily breakfast and 1.3 folds risk if student did not consume 4 - 5 meals daily. There was also 1.6 and 1.5 folds increase in risk of IDA if the meal contains chips (fried potato) or if the meal was accompanied by soft drinks, respectively. Moreover, there was 1.3 folds risk of IDA if the meal did not contain fruits and vegetables and for meal that did not contain spinach or lettuce. Further, there was 2.1 folds increase in risk of IDA when meal does not contain nuts. On the other hand, the risk decreased to the half if meal contains liver, or if the meal wasn't followed by tea drink ${ }^{1}$.

The impact of participants Body Mass Index (BMI) on anemia risk was studied. Before doing that, they were categorized according to their BMI as shown in table 3 below. It was shown that 98 female students (49.0\%) had normal weight, 19 (9.5\%) were underweight, $12.0 \%$ were overweight and $2.5 \%$ were obese.

Hemoglobin categories versus BMI distribution of students were also analyzed and the results were shown in table 4 . The data revealed that females across all BMI categories were suffering from mild to moderate anemia. Only one male student who was overweight, was suffering from mild anemia.

Furthermore, one-Way ANOVA test for differences in anemia prevalence due to different BMI categories was performed. Results showed a significance difference at $\alpha \leq 0.05$ between underweight and overweight groups, (See table $5^{2}$ ).

\begin{tabular}{|l|c|c|c|c|}
\hline \multirow{2}{*}{ Categories of BMI } & \multicolumn{2}{c|}{ Gender } & \multirow{2}{*}{ Total } \\
\cline { 3 - 5 } & Male & Female & \\
\hline \multirow{2}{*}{ Underweight } & \multirow{2}{*}{ Count \% of Total } & 0 & 19 & 19 \\
\cline { 3 - 5 } & & $0.0 \%$ & $9.5 \%$ & $9.5 \%$ \\
\hline \multirow{2}{*}{ Novmal } & Count \% of Total & 30 & 98 & 128 \\
\cline { 3 - 5 } & & $15.0 \%$ & $49.0 \%$ & $64.0 \%$ \\
\hline \multirow{2}{*}{ Obese } & \multirow{2}{*}{ Count \% of Total } & 19 & 24 & 43 \\
\cline { 3 - 5 } & & $9.5 \%$ & $12.0 \%$ & $21.5 \%$ \\
\hline Total & & 5 & 5 & 10 \\
\cline { 3 - 5 } & & $2.5 \%$ & $2.5 \%$ & $5.0 \%$ \\
\hline \multirow{2}{*}{ Count \% of Total } & 54 & 146 & 200 \\
\cline { 3 - 5 } & & $27.0 \%$ & $73.0 \%$ & $100.0 \%$ \\
\hline
\end{tabular}

Table 3: Categories of body mass index (BMI) and gender cross-tabulation.

\section{Discussion}

The results of this study was both surprising and interesting. We found that $22 \%$ of randomly selected healthy university students on campus had lower than normal hemoglobin levels. Majority of these students were aware of signs and symptoms of anemia.

Actually, when interrogating some of students informally during the interview-administered questionnaire, they were suffering of few symptoms of low hemoglobin. These symptoms were not severe enough to affect their daily activities nor were they warranting a physician visit. Excluding all other forms of anemia or low or impaired function of RBC such as thalassemia or sickle cell anemia, our results might suggest a form of iron deficiency or impaired iron-binding capacity rather than a clinical manifestation or true anemia or IDA. It was also shown that $23 \%$ of female students had $\mathrm{Hb}$ levels $<12 \mathrm{gm} / \mathrm{dl}$ ). These results matched the results of Al-Sayes., et al. [20] study where $23.9 \%$ of apparently healthy university students had IDA and $25.9 \%$ had deficient iron store. These results in agreement with other studies that showed females are at higher risk of RBCs disorders. This is presumably due to some hereditary and genetic disorders, especially among Mediterranean countries [21].

On the other hand, prevalence results in this study were controversial to results in Mikki., et al. [12] study. While the prevalence

\footnotetext{
${ }^{1}$ Odds ratio results are available from authors upon request.

${ }^{2}$ One-Way ANOVA tests was also applied separately to parents' education, monthly income, and career. Results showed no significant differences at $\alpha \leq$ 0.05 on anemia risk.
} 


\begin{tabular}{|c|c|c|c|c|c|c|c|c|}
\hline \multirow{2}{*}{\multicolumn{4}{|c|}{ Gender }} & \multicolumn{4}{|c|}{ Categories of body mass index } & \multirow{3}{*}{$\begin{array}{c}\text { Total } \\
1\end{array}$} \\
\hline & & & & \multirow{2}{*}{ Underweight } & \multirow[t]{2}{*}{ Normal } & \multirow{2}{*}{$\begin{array}{c}\text { Overweight } \\
1\end{array}$} & \multirow[t]{2}{*}{ Obese } & \\
\hline Male & Hemoglobin & Mild anemia & Count & & & & & \\
\hline & & & $\%$ of Total & & & $100.0 \%$ & & $100.0 \%$ \\
\hline & \multirow{2}{*}{\multicolumn{2}{|c|}{$\begin{array}{l}\text { Total } \\
\% \text { of Total }\end{array}$}} & Count & & & 1 & & 1 \\
\hline & & & & & $100.0 \%$ & & $100.0 \%$ & \\
\hline \multirow[t]{6}{*}{ Female } & \multirow{4}{*}{$\begin{array}{l}\text { Hemoglobin } \\
\text { categories }\end{array}$} & \multirow{2}{*}{$\begin{array}{l}\text { Moderate } \\
\text { anemia }\end{array}$} & Count & 2 & 10 & 3 & 0 & 15 \\
\hline & & & $\%$ of Total & $4.7 \%$ & $23.3 \%$ & $7.0 \%$ & $0.0 \%$ & $34.9 \%$ \\
\hline & & \multirow[t]{2}{*}{ Mild anemia } & Count & 7 & 15 & 4 & 2 & 28 \\
\hline & & & $\%$ of Total & $16.3 \%$ & $34.9 \%$ & $9.3 \%$ & $4.7 \%$ & $65.1 \%$ \\
\hline & \multirow{2}{*}{\multicolumn{2}{|c|}{$\begin{array}{c}\text { Total } \\
\% \text { of Total }\end{array}$}} & Count & 9 & 25 & 7 & 2 & 43 \\
\hline & & & $20.9 \%$ & $58.1 \%$ & $16.3 \%$ & $4.7 \%$ & $100.0 \%$ & \\
\hline \multirow[t]{6}{*}{ Total } & \multirow{4}{*}{$\begin{array}{l}\text { Hemoglobin } \\
\text { categories }\end{array}$} & \multirow{2}{*}{$\begin{array}{l}\text { Moderate } \\
\text { anemia }\end{array}$} & Count & 2 & 10 & 3 & 0 & 15 \\
\hline & & & $\%$ of Total & $4.5 \%$ & $22.7 \%$ & $6.8 \%$ & $0.0 \%$ & $34.1 \%$ \\
\hline & & \multirow[t]{2}{*}{ Mild anemia } & Count & 7 & 15 & 5 & 2 & 29 \\
\hline & & & $\%$ of Total & $15.9 \%$ & $34.1 \%$ & $11.4 \%$ & $4.5 \%$ & $65.9 \%$ \\
\hline & \multicolumn{2}{|c|}{ Total } & Count & 9 & 25 & 8 & 2 & 44 \\
\hline & \multicolumn{2}{|c|}{$\%$ of Total } & $20.5 \%$ & $56.8 \%$ & $18.2 \%$ & $4.5 \%$ & $100.0 \%$ & \\
\hline
\end{tabular}

Table 4: Hemoglobin categories along with BMI and gender cross-tabulation.

\begin{tabular}{|c|c|c|c|c|c|}
\hline Hemoglobin & Sum of Squares & df & Mean Square & F & Sig. \\
\hline Between Groups & 45.387 & 3 & 15.129 & 4.970 & .002 \\
\hline Within Groups & 596.615 & 196 & 3.044 & & \\
\hline Total & 642.001 & 199 & & & \\
\hline
\end{tabular}

Table 5: One-way ANOVA test for Differences in anemia and BMI among participants

(DF: Degree of Freedom; F: Multivariate Distribution; Sig: Significance).

of anemia among females in our study was closer to the results among adolescents (boys) in Hebron city, it was way higher than that in females in Mikki study. Being mostly females, we should be careful in interpreting our results. We should take into consideration menstrual cycle blood loss and low $\mathrm{Hb}$ levels in general around female monthly period.

Our results were better than that showed by Shill KB., et al. [22], where $55 \%$ of randomly chosen students were anemic. However, $50 \%$ of students were males in Shill study and that explains the higher level of hemoglobin among their samples comparing to ours. Also, the level of awareness of anemia in their student was way lower than ours.

When it comes to BMI and its relation to low hemoglobin levels, $20 \%$ of anemic female students were underweight. This could be contributed to adopting restrictive weight loss regimen programs by all or some of these female students, fast food dependent diet or low nutritional and caloric value diet.
It was found that $22.7 \%$ of students who have low $\mathrm{Hb}$ levels were either overweight or obese. This finding is in agreement with a study that linked overweight to low Hb levels [23]. In a sense, overweight might be due to inadequate dietary habits as a response to negative iron balance. This is one of the main findings of this study where we found a strong relation between poor dietary habits, obesity and negative iron balance.

On the other hand, $57 \%$ of students who have low $\mathrm{Hb}$ levels have normal BMI. This simply means that normal BMI doesn't rule out IDA in apparently healthy students. However, Tukey test results revealed that low BMI influenced low Hb levels among subjects of our study. Ferritin levels that confirm IDA, weren`t determined for these students, which is one of the main drawbacks of our study.

However, we designed the questionnaire in a way to capture all dietary habits that lead to inadequate iron intake or inadequate iron absorption. This conveys that low Hb levels among subjects of this study, were due to iron deficiency. 
In an Iranian study by Shams S., et al. [24], only 3.8\% of 237 female medical students had IDA and $40.9 \%$ had ID (iron deficiency) when a restrict criteria to define IDA using Hb levels, MCV, serum ferritin, serum iron and total iron-binding capacity levels was used. This came in harmony with our conclusion of the importance of measuring iron-binding capacity and the reasons for iron-binding problem at the level of gene and to further elucidate on functional anemia or iron impairment [25].

A closer look to diet of these students, revealed that they consumed healthy diets. In Palestine, having meat, beans, fruits and vegetables as part of a meal is usual. When it comes to dietary habits, participants rated moderately the importance of drinking milk or tea after food. Both drinks prevent iron absorption. Students also rated moderately the importance of consuming iron-rich foods, such as lattice and spinach. Adding to the problem students have low level of knowledge of important aspects of anemia.

It was proven that IDA can't be treated with iron-rich diet alone. Nevertheless, subjects of the study failed to define the relationship between iron deficiency and anemia and thought that drinking tea increases iron absorption. On the other hand, they were able to recognize signs and symptoms of anemia, but we have to be careful in interpreting or extrapolating this knowledge to the public since $73 \%$ of participants are females. Female students have more knowledge about signs and symptoms of iron deficiency they might encounter during menstrual period. Females are very sensitive to hair loss too. They probably visited the dermatologist for hair loss where he/she discovered they have anemia and hair loss was just a sign.

This represents the female gender trend of this study. It might only reflect an individual state of awareness of signs and symptoms of anemia due to personal experience. It doesn't reflect general awareness of the public.

There was 1.3 - 2.1 folds increase in risk of IDA in students who had poor dietary habits in this study. The risk decreased to the half when the meal contains liver, or when the meal does not contain tea. This comes in agreement with findings of a study by Frank F. in 2016 that showed the correlation between excessive green tea drinking and IDA [26]. Despite the fact most students came from high income families with educated parents, we could not find any significant effect for parents occupation, education or income on IDA.

\section{Conclusion}

New diagnostic tools and/or novel biomarkers are needed to predict pre-anemic and/or hidden Iron Deficiency or iron-binding capacity among healthy subjects. Educating families and students about early and / or late signs and symptoms of iron deficiency is crucial for preventing anemia.

\section{Acknowledgement}

We would like to thank Dr. Amjad El Barbarawi at Al Esraa Lab for his support. We specially acknowledge the $5^{\text {th }}$ year pharmacy students, Zahra Tomiz, Ghadeer Abu Awwad, and Kholoud Abu Aqeil for their participation in data collection. Special thanks for Dr. Haddad Abdel Raheem for proof reading of the manuscript.

\section{Ethical Approval}

Permission to run the research on campus was taken from the Higher Research and Graduate studies deanship office of the university. Ethical approval was granted by The Internal Review Committee at the university. Blood sample collection was done under supervision of the medical laboratory department and University Clinic Attending physician according to Helsinki research and human sample collection mandates. Consent form was signed by each student before participation.

\section{Consent Form}

Each participant signed an informed consent explaining the nature of the study and the confidentiality of his identity and all other personal and/or health data collected from them. In addition to their right to withdraw from the study at any stage.

\section{Conflict of Interest}

The authors declare no competing financial conflict of interest.

\section{Bibliography}

1. Wiwantkit V. "Tropical Anemia". Nova Science Publishers Inc (2008).

2. Allison R. "Everything you need to know about anemia". The Rosen Publishing Group, Inc (2002).

3. How is iron deficiency diagnosed (2018).

4. Janz TG., et al. "Anemia in the Emergency Department: Evaluation and Treatment". Emergency Medicine Practice 15.11 (2013): 1-15.

5. Stevens GA., et al. "Global, regional, and national trends in hemoglobin concentration and prevalence of total and severe anemia in children and pregnant and non-pregnant women for 1995-2011: a systematic analysis of population-representative data". Lancet Glob Health 1.1 (2013): e16-e25. 
6. Balarajan Y., et al. "Anemia in low-income and middle-income countries". The Lancet 378.9809 (2011): 2123-2135.

7. Shaw G and Friedman J. "Iron Deficiency Anemia: Focus on Infectious Diseases in Lesser Developed Countries". Anemia (2011): 1-10.

8. Rani NA., et al. "Prevalence of Nutritional Deficiency Anemia and Its Impact on Scholastic Performance among Undergraduate Medical Students". Journal of Clinical and Diagnostic Research 11.3 (2017): BC21-BC23.

9. Cavendish Marshall. "Disease and disorder". amazon.com (2008).

10. Cotter and Susan M. "Hematology". CRC Press Book (2001).

11. Sachdeva A. "Practical Pediatric Hematology". Amazon.com (2012).

12. Mikki N., et al. "Anaemia prevalence and associated sociodemographic and dietary factors among Palestinian adolescents in the West Bank". Eastern Mediterranean Health Journal 17.3 (2011): 208-217.

13. Sirdah M., et al. "Iron deficiency anemia among kindergarten children living in the marginalized areas of Gaza Strip, Palestine". Revista Brasileira de Hematologia e Hemoterapia 36.2 (2014): 132-138.

14. Hashizume M., et al. "Anaemia in relation to low bioavailability of dietary iron among school-aged children in the Aral Sea region, Kazakhstan". International Journal of Food Sciences and Nutrition 55.1 (2004): 37-43.

15. Abalkhail B and Shawky S. "Prevalence of daily breakfast intake, iron deficiency anaemia and awareness of being anemic among Saudi school students". International Journal of Food Sciences and Nutrition 53.6 (2002): 519-528.

16. Asobayire F., et al. "Prevalence of iron deficiency with and without concurrent anemia in population groups with high prevalence of malaria and other infections". The American Journal of Clinical Nutrition 74.6 (2001): 776-782.

17. Schaefer R and Huch R. "Iron deficiency and Iron deficiency anemia”. amazon.com (2006).

18. Habib MA., et al. "Prevalence and Predictors of Iron Deficiency Anemia in Children under Five Years of Age in Pakistan, A Secondary Analysis of National Nutrition Survey Data 20112012". PLoS ONE 11.5 (2016): e0155051.
19. Özdemir N. "Iron deficiency anemia from diagnosis to treatment in children". Turkish Archives of Pediatrics 50.1 (2015): 11-19.

20. Al-Sayes F., et al. "Prevalence of iron deficiency and iron deficiency anemia among females at university stage". Journal of Medical Laboratory and Diagnosis 2.1 (2011): 5-11.

21. Steensma D., et al. "Hereditary Red Blood Cell Disorders in Middle Eastern Patients”. Mayo Clinic Proceedings 76 (2001): 285-293.

22. Shill KB., et al. "Prevalence of iron-deficiency anaemia among university students in Noakhali region, Bangladesh". Journal of Health, Population and Nutrition 32.1 (2014):103-110.

23. Bagni UV., et al. "Overweight is associated with low hemoglobin levels in adolescent girls". Obesity Research and Clinical Practice 7.3 (2013): e218-e229.

24. Shams S., et al. "The prevalence of iron deficiency anemia in female medical students in Tehran". Singapore Medical Journal 51.2 (2010): 116-119.

25. Jain M and Sharma S. "Iron deficiency and anemia". Indian Journal of Fundamental and Applied Life Science 2.2 (2012):101107.

26. Fan FS. "Iron deficiency anemia due to excessive green tea drinking". Clinical Case Reports 4.11 (2016):1053-1056.

\section{Assets from publication with us}

- Prompt Acknowledgement after receiving the article

- Thorough Double blinded peer review

- Rapid Publication

- Issue of Publication Certificate

- High visibility of your Published work

Website: https://www.actascientific.com/

Submit Article: https://www.actascientific.com/submission.php Email us: editor@actascientific.com

Contact us: +919182824667 